\title{
Renovating paspalum pastures by direct drilling ryegrass -
} is it worthwhile?

E.R. THOM, D.D. WILDERMOTH and M.J. TAYLOR Dairying Research Corporation, Ruakura Agricultural Centre, Private Bag, Hamilton

\section{Abstract}

A5-year experiment at Ruakura Agricultural Centre measured the effects of blanket application of glyphosate herbicideand direct drilling ofperennial ryegrass and white clover on seasonal pasture composition and production. Plots wcre sprayed in autumn 1985 with 6,4,2 and 0 tha of glyphosate before direct drilling with a mixture of 'Ellett' ryegrass and 'Grasslands Kopu' white clover. These treatments werecompared with plots of the original paspalum pasture which was not sprayed or drilled. Plots were arranged at random in 6 replicate blocks that were rotationally grazed by dairy cows. Applying high rates (4-6 1/ha) of glyphosate completely eliminated paspalum from the pasture and subsequently, treatment differences between the 6 and 4 1/ha treatments for most variables were small. Differences in winter/spring herbage accumulation between the 4 l/ha treatment and the control plots were highest in the first year and declined with time, representing $1.9,0.8,0.8,0.6$ and $0.4 \mathrm{t} \mathrm{DM} / \mathrm{ha}$, respectively, over the $\mathrm{S}$ years of the trial. The declining growth response was paralleled by an increasing level of paspalum in the previously sprayed plots, which exceeded 30\% of DM by the fourth summer. Over the same period, their summer ryegrass contents had declined by more than half (46-20\% of DM). These results suggest that for this site further renovation using glyphosate (at 4 1/ha) would be beneficial after 4 years to recapture the immediate superior growth responses, and since the costs of renovation could be met within 2 years.

Keywords Paspalum dilitatum, Lolium perenne, seasonal herbage accumulation, renovation methods, glyphosate herbicide, dairy pastures, volunteer paspalum invasion, pasture botanical composition stability

\section{Introduction}

In northernNew Zeeland, volunteerpaspalum (Paspalum dilatatum Poir.) is common in pastures where perennial ryegrass (Lolium perenne L.) has lost vigour or plant numbers have been reduced after stress periods like severe grazing during summer drought and pugging in winter.

When summer-growing paspalum constitutes more than $25 \%$ of the herbage mass, potential feed production during winter/spring can be reduced (Thom et al. 1987), with the possibility of reduced cow performance.

Perennial ryegrass is commonly undersown (direct drilled) in autumn during pasture renovation. Paspalum, how ever, is a persistent rhizomatous species which offers severe competition to undersown ryegrass. This competition can be reduced by blanket herbicide application before drilling (spray/drilling).

This paper provides 5 years of data from an experiment which measured the effects of blanket application of glyphosate (Roundup herbicide and direct drilling of perennial ryegrass and white dover on seasonal pasture composition and production. Thōm (1988)presentedapreliminaryreportonthefiit 2years of this experiment This experiment provided a unique opportunity to monitor the long-term stability of a ryegrass pasture established on a site previously dominated by volunteer paspalum.

\section{Materials and methods}

site

The experiment was conducted at the Ruakura A gricultural Centre on 6 adjacent 0.25 ha paddocks covering well-drained Bruntwood silt loam and imperfectly drained Te Kowhai silt loam soils. Further details of regional climate, fertiliser inputs and prestudy pasture composition are given in Thom (1988). 


\section{Experimental design and treatments}

The treatments wereoriginalpasture and blanket spraying with $0,2,4$ and 61 of glyphosate in 2001 water/ha. Sprayed plots were direct drilled on 21 March 1985 with a mixture of high endophyte 'Ellett' ryegrass (18 kg/ha) and 'Grasslands Kopu' whiteclover ( $3 \mathrm{~kg} / \mathrm{ha}$ ). Details of the establishment methods are given in Thorn (1988) Treatment plots were arranged in a randomised block design with 6 replications.

The experiment began with the spraying of the plots on 12 March 1985 and concluded in June 1990. During the experiment the plots were grazed by dairy cows on 51 occasions, the first 47 days after drilling. Average stocking densities were 160 cows/ha for 6 hours of grazing. Averagepre- and post-grazing herbage masses were 2.9-3.0 t DM/ha and 1.6-1.7 t DM/ha, respectively.

\section{Sward measurements}

Standard methods were used for botanical composition and tiller density measurements (Thorn 1988). Seasonal growth rates and yields were calculated from visual estimates ofherbagemass made ateach grazing. Seasonal yields were obtained by summing growth differences betweenpost-grazingestimatesandthenextpre-grazing estimates for winter/spring (May-October) and summer/ autumn (November-April).

\section{Results}

For many variables, treatment differences between the 6 and $4 \mathrm{I} / \mathrm{ha}$ treatments were small and non-significant. Comparisons are therefore often presented for only the 4 l/ha (now the label rate for paspalum control with glyphosate), the $21 / \mathrm{ha}$, the undersown treatment plots $(0$ 1/ha) and the control plots (original pasture).

\section{Paspalum status}

The paspalum content of pastures before herbicide application in March 1985 was similar for all treatment plots, averaging $38 \%$ of DM. Paspalum was reduced to a low level in the plots receiving a low rate of herbicide and was completely eliminated where high herbicide rates were applied (4-6 1/ha) (Table 1). Peak paspalum levels occurred in summer/autumn (January-April). Paspalum content of sprayed pastures progressively increased during the experiment and by January 1989 had exceeded $30 \%$ of DM, maintaining similar levels until the end of the experiment.

Tiller density data confirm this trend (Figure 1). During the 2 years after spraying, paspalum tiller densities were lower where high rates (4-6 1/ha) of glyphosate wereused, but by February 1987 differences betweenthehighandlow (2l/ha)herbicide rate treatments had become small and non-significant. During the last 2 years of the trial, paspalum tiller density did not differ among treatments. Tiller density in the 6,4 and $21 /$ ha treatment plots was highest in June 1990, averaging 897 paspalum tillers/m* compared with 787 for undersown and control plots.

Table 1 Changes in the paspalum content (\% of DM) of pastures during the experiment.

\begin{tabular}{lcccccr}
\hline Date & \multicolumn{5}{c}{ Treatment } \\
\cline { 2 - 5 } & 4 l/ha & 2 l/ha & 0 & l/ha & Control & LSD \\
\hline 30 April 1985 & 0 & 2 & 13 & 10 & 3.9 \\
28 February 1986 & 4 & 4 & 27 & 44 & 9.9 \\
12 January 1987 & 14 & 22 & 30 & 47 & 9.3 \\
7 January 1988 & 12 & 12 & 20 & 18 & 10.0 \\
31 January 1989 & 35 & 47 & 58 & 34 & 10.7 \\
3 April 1990 & 27 & 31 & 23 & 34 & 14.9 \\
\hline a LSD = least sianificant difference. P<0.05 &
\end{tabular}

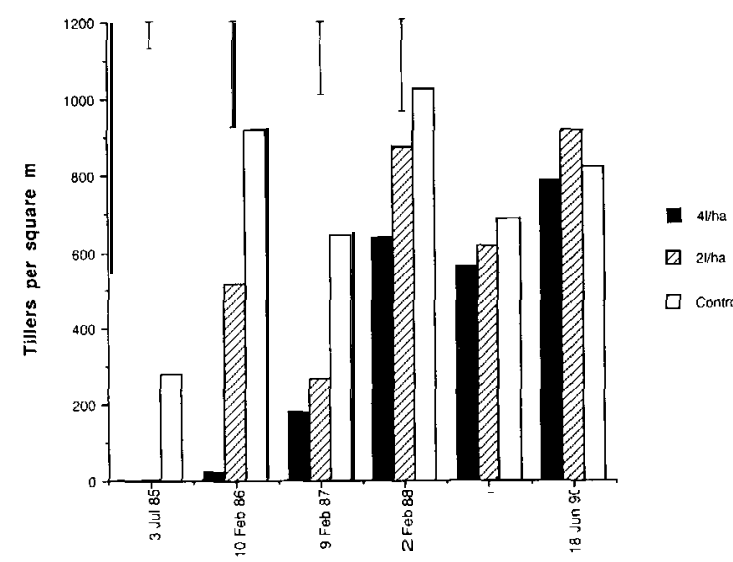

Figure 1 Paspalum tiller density (tillers $\&$ ) in pastures over a 5 year period following spraying with glyphosate in March 1985. Vertical lines are LSD $(P<0.05)$ levels.

\section{Ryegrass status}

A similar ryegrass content existed in all treatment plots in March 1985 (averaging 29\% of DM) before herbicide application. Sprayed plots contained more ryegrass in summer than did control plots in 1986.1987 and 1988 , but differences were small and non-significant in the last year (Table 2). During 1989 and 1990, ryegrass content during summer/autumn was less than March 1985 levels (averaging $20 \%$ of DM). Ryegrass levels in undersown plots were intermediate between plots receiving 2 l/ha of glyphosate and the control plots. 
Table 2 Changes in the ryegrass content (\%o of DM) of pastures during the experiment.

\begin{tabular}{|c|c|c|c|c|c|}
\hline \multirow[t]{2}{*}{ Date } & \multicolumn{4}{|c|}{ Treatment } & \multirow[b]{2}{*}{$\operatorname{LSD}^{\mathbf{a}}$} \\
\hline & $4 \mathrm{l} / \mathrm{ha}$ & 2 l/ha & 0 l/ha & Control & \\
\hline 30 April 1985 & 41 & 38 & 47 & 42 & 14.0 \\
\hline 28 February 1986 & 48 & 44 & 29 & 15 & 9.8 \\
\hline 12 January 1987 & 37 & 24 & 20 & 15 & 11.5 \\
\hline 7 January 1966 & 32 & 33 & 31 & 28 & 9.0 \\
\hline 31 January 1989 & 21 & 17 & 14 & 19 & 6.7 \\
\hline 3 April 1990 & 23 & 20 & 25 & 20 & 9.2 \\
\hline
\end{tabular}

\section{Other pasture components}

The white clover content of the pastures were not affected by treatments, apart from immediately after herbicide application (see Thorn 1988). andranged from $18-40 \%$ of DM, depending on season. Dead material was the other major component of the pasture which, apart from the effects of herbicide application in autumn 1985 (see Thorn 1988), ranged from $20-30 \%$ of DM in summer/ autumn and $2-12 \%$ of DM in winter/ spring. Weeds and other grasses were usually less than $10 \%$ of DM.

\section{Seasonal yields}

Pasture herbage accumulation from drilling until the first grazing (21 March-6 May 1985) was on average lower for the sprayed $(-1.1 \mathrm{t} \mathrm{DM} / \mathrm{ha})$ than for undersown and control plots (1.0 t DM/ha), reflecting the effects of the herbicide on plant death and loss of dry matter. Accumulationduring winter/spring in sprayed plots was greater than in unsprayed plots from 1985 until 1988 (Table 3), but treatment differencesbccameprogressively smaller as the pasture aged (Figure 2). Undersowing produced much smaller but consistent advantages over the control, than did the plots sprayed before drilling.

There was a tendency for unsprayed plots to accumulate more dry matter over summer/autumn than did sprayed plots, but differences were usually small and non-significant. Summer/autumnherbage accumulations ranged from 8-13.6 $\mathrm{t} \mathrm{DM} / \mathrm{ha}$ over the trial period.

Table 3 Herbage yields (t DM/ha) over consecutive cool seasons.

\begin{tabular}{|c|c|c|c|c|c|}
\hline \multirow[t]{2}{*}{ Period } & \multicolumn{4}{|c|}{ Treatment } & \multirow[b]{2}{*}{$\operatorname{LSD}^{\mathrm{a}}$} \\
\hline & 4 l/ha & 2 l/ha & $0 \mathrm{l} / \mathrm{ha}$ & Control & \\
\hline $8.5 .85 \cdot 7.10 .85$ & 6.2 & 5.7 & 4.8 & 4.3 & 0.75 \\
\hline $29.5 .86 \cdot 28.10 .86$ & 4.2 & 4.1 & 3.6 & 3.4 & 0.48 \\
\hline $30.4 .87 \cdot 8.10 .87$ & 4.1 & 4.0 & 3.7 & 3.3 & 0.54 \\
\hline $22.4 .88 \cdot 5.10 .88$ & 4.2 & 4.2 & 3.8 & 3.6 & 0.52 \\
\hline $26.5 .89 \cdot 9.10 .89$ & 3.9 & 3.6 & 3.6 & 3.5 & 0.27 \\
\hline
\end{tabular}

Figure2 Extraherbage accumulation during winter/spring (t DM/ha) on treatment plots compared to the controls (original pasture) over a S-year period. Vertical lines are LSD $(P<0.05)$ levels.

\section{Cost-benefit analysis}

A simple cost-benefit analysis was used to estimate the value of the extra dry matter produced in winter/spring for pastures sprayed before drilling and undersown pastures, when compared with the original pasture (control) (Table 4).

Table 4 Cost-benefit analysis for renovation of paspalum pastures.

\begin{tabular}{lcc}
\hline & $\begin{array}{c}\text { Sprayed } \\
(41 / \mathrm{ha})\end{array}$ & Undersown \\
\hline $\begin{array}{l}\text { Total extra dry matter produced over } \\
5 \text { years (kg DM/ha) }\end{array}$ & 4500 & 1400 \\
Assume 85\% utilisation (kg DM/ha) & 3825 & 1190 \\
Assume $20 \mathrm{~kg}$ DM produces 1 kg milkfat & 191 & 59 \\
(kg of milkfat) & & \\
Assume 1 kg milkfat Is worth \$4 (\$) & 764 & 236 \\
Costs (\$) & $525^{\mathbf{a}}$ & $100^{\mathrm{b}}$ \\
Net return (\$) & 239 & 136 \\
\hline
\end{tabular}

For a 60 ha dairy farm renovating $15 \%$ or

9 ha of pasture:

Net return $(\$ /$ farm)

$2151 \quad 1224$

Includes direct costs (seed, herbicide, contract rates for drilling and herbicide application) and indirect cost of loss of autumn grazing equivalent to $2100 \mathrm{~kg}$ DM/ha.

b Includes direct costs (seed, contract rates for drilling) and assumes indirect costs are small.

\section{Discussion}

This trial was designed to demonstrate the extent that major changes in pasture botanical composition brought 
about by renovation can persist. The results show that the positive yield effects of herbicide application before drilling were large during the first year but had disappeared by the fourth year, as paspalum once again became the major pasture component exceeding the level of $25 \%$ of DM suggested by Thorn $\boldsymbol{e t}$ al. (1987), when reduced winter/spring growth potential is possible Visual examination of the pastures after spraying with high rates of glyphosate (46 l/ha) suggested complete kill of the resident paspalum. Regeneration from volunter seed was likely since paspalum contributed about $40 \%$ of the pasture dry matter production before spraying.

Dollar returns from spray/drilling are likely to be higher because of the large initial growth response of the new ryegrass plants sown into a relatively competitionfree environment compared to when undersown into established plants. This experiment allowed the overall benefits in terms of extra herbage production to be assessed and indicates that at least for this site, renovation every 4 years is appropriate.

\section{Conclusions}

Renovation of paspalum pastures is considered worthwhile since the costs of renovation using glyphosate herbicide can be repaid in 2 years, and the costs of undersowing in 1 year. Another renovation of the trial site could have been considered 4 years from drilling in order to recapture the superior gains in winter/spring herbage accumulation that occurred immediately postdrilling.

\section{ACKNOWLEDGEMENTS}

We thank the field staff of the Dairying Research Corporation, Ruakura, for help in carrying out this experiment. N.R. Cox provided statistical advice and P.A. Allison and R.N. Gillespie technical assistance.

\section{REFERENCES}

Thom,E.R. 1988. Changingseasonalgrowthofpaspal um pastures by overdrilling ryegrass and white dover. Proceedings of the NZ Grassland Association 49: 135-140.

Thom,E.R.; Prestidge, R.A.;B arker,G.M. 1987. Pasture establishment on the dairy farm. Proceedings of the Ruakura Farmers' Conference 39: 50-52. 